\title{
PARAMETER POPULASI IKAN KAKAP MERAH (Lutjanus malabaricus) DI PERAIRAN LAUT CINA SELATAN
}

\section{FISH POPULATION PARAMETER OF RED SNAPPER (Lutjanus malabaricus) IN SOUTH CHINA SEA}

\author{
Nurulludin ${ }^{1 \#}$, Khairul Amri ${ }^{2}$ dan Pratiwi Lestari ${ }^{2}$ \\ ${ }^{1}$ Pusat Riset Perikanan \\ Jl. Pasir Putih II, Ancol Timur, Jakarta Utara !4430 \\ ${ }^{2}$ Balai Riset Perikanan Laut \\ Jl. Raya Bogor KM. 47, Cibinong \\ E-mail: nurulludin@kkp.go.id
}

(Diterima: 12 Maret 2019; Diterima setelah perbaikan: 1 September 2019; Disetujui: 1 September 2019)

\begin{abstract}
ABSTRAK
Ikan kakap merah merupakan salah satu ikan demersal yang rentan terhadap penangkapan dan mempunyai pengaruh dalam keseimbangan ekosistem. Penelitian dilakukan pada Mei-Desember 2015. Pengambilan data sebanyak 669 ekor ikan kakap merah di wilayah pendaratan ikan Belitung yang termasuk dalam wilayah Laut Cina Selatan. Hasil analisis diperoleh beberapa parameter populasi ikan kakap merah (Lutjanus malabaricus) memiliki koefisien pertumbuhan $(=\mathrm{K})$ sebesar 0,21 per tahun dan panjang asimtotik (=L") $86,10 \mathrm{~cm}$. Laju mortalitas alami (=M) 0,49 pertahun dan mortalitas penangkapan (F) sebesar 0,59 per tahun, sehingga diperoleh nilai kematian total $(=\mathrm{Z}) 1,08$ pertahun. Panjang pertama kali tertangkap $(=\mathrm{Lc})$ sebesar 38,2 cmTL dan panjang pertama kali matang gonad $(=\mathrm{Lm})$ 45,6 cmTL. Status tingkat pemanfaatan ikan kakap merah $(=\mathrm{E})$ sebesar 0,55. Tingkat pemanfaatan ikan kakap sudah over exploited sebesar 9 persen dari kondisi optimum.
\end{abstract}

\section{KATA KUNCI: Pertumbuhan; tingkat pemanfaatan; Laut Cina Selatan}

\begin{abstract}
The red snapper as one of the demersal fish are prone to catching and have an influence on the balance of the ecosystem. The study was conducted in May-December 2015. Data collection of 669 red snapper fishes in the landing area of Belitung are included in the South China Sea region. The analysis obtained several population parameters of red snapper (Lutjanus malabaricus) has a coefficient of growth (=K) of 0.21 per year and asymptotic length $(=L ”) 86.10 \mathrm{~cm}$, The rate of natural mortality $(=M) 0.49$ arrests per year and mortality $(F)$ of 0.59 per year, so that the value of total mortality $(=Z) 1.08$ per year. Length at first captured $(=L c) 38.2 \mathrm{cmTL}$ and length at first maturity $(=\mathrm{Lm}) 45.6 \mathrm{cmTL}$. Status utilization rate of red snapper $(=E)$ of 0.55 . The utilization rate of snapper fish has been over exploited by 9 percent from the optimum conditions.
\end{abstract}

KEYWORDS: Growth; utilization rate; South East Cina Sea

\footnotetext{
\# Korespondensi: Pusat Riset Perikanan

E-mail: nurulludin@kkp.go.id
} 


\section{PENDAHULUAN}

Ikan kakap merah merupakan salah satu ikan demersal yang menjadi spesies dominan di Perairan Laut Cina Selatan (LCS). Terkait dengan masih jarangnya penelitian di LCS yang khusus ditujukan untuk mengkaji status dan perkembangan sumber daya perikanan ini, maka penelitian menyangkut aspek parameter populasi sumber daya ikan kakap merah menjadi sangat penting untuk dilakukan. Penelitian tentang ikan ini pernah dilakukan di beberapa tempat oleh Fry et.al. (2009), Newman (2002), Edward (1991), Herianti (1993), Prihatiningsih (2012), dan Wahyuningsih (2013).

Ikan kakap merah juga rentan terhadap penangkapan, meskipun menurut. Ikan ini juga memiliki aktivitas gerak yang rendah, gerombolan (Schooling) ikan yang kecil, migrasi tidak terlalu jauh dan mempunyai daur hidup lama (Sriati, 2011; Fry \& Milton, 2009). Habitat ikan kakap merah yang berada di Laut Cina Selatan berada pada kisaran kedalaman di atas 30-40 meter (Perangin-angin et al., 2016).

Perikanan demersal ditangkap menggunakan alat tangkap tradisional diperairan pesisir hampir semua negara yang berbatasan dengan SCS (McManus et al., 2010), dengan target hasil tangkapan yang relatif multi spesies (George 2012). Ikan kakap merah (Lutjanus malabaricus) di Perairan Belitung, Laut China Selatan ditangkap menggunakan pancing ulur dan bubu kayu. Kapal bubu yang menangkap ikan kakap merah di Belitung beroperasi 7 (Tujuh) hari laut dan pancing beroperasi harian (one day fishing).

Penelitian ini bertujuan untuk menganalisis beberapa aspek parameter populasi seperti rata-rata panjang pertama kali tertangkap (Lc), Panjang pertama kali matang gonad (Lm), panjang infinity (L"), Pertumbuhan (K), tingkat kematian alami (M), tingkat kematian akibat penangkapan (F) dan laju eksploitasi (E) dari ikan kakap merah (Lutjanus malabaricus) sebagai acuan dalam pengelolaan / pemanfaatan sumber daya ikan kakap merah.

\section{BAHAN DAN METODE}

\section{Waktu dan Lokasi Penelitian}

Penelitian dilakukan pada Mei - Desember 2015. Pengambilan data penelitian mencakup ikan yang didaratkan di Pelabuhan Perikanan Nusantara (PPN) Tanjung Pandan, pasar ikan dan tempat pengumpul ikan (tangkahan). Sampel ikan kakap merah (Lutjanus malabaricus) diperoleh 669 ekor dari hasil tangkapan kapal yang menggunakan alat tangkap pancing ulur, bubu dan payang dalam kurun waktu 8 (delapan) bulan.

\section{Analisis Data}

\section{Hubungan panjang-bobot}

Hubungan panjang-bobot mengacu pada Effendie (1979) dengan formula:

$\mathrm{W}=\mathrm{aL}^{\mathrm{b}}$

Di mana :

$\mathrm{W}=$ bobot

$\mathrm{L}=$ panjang

a = intersep (perpotongan kurva hubungan panjangbobot dengan sumbu Y)

$\mathrm{b}=$ kemiringan (slope)

Untuk menguji nilai b $=3$ atau b " 3 dilakukan uji $-t$ (uji parsial), dengan hipotesis:

$\mathrm{H}_{0}: \mathrm{b}=3$, hubungan panjang dan bobot adalah issometrik.

$\mathrm{H}_{1}$ : $\mathrm{b}$ '“3 3 , hubungan panjang dengan bobot adalah allometrik yaitu :

Pola hubungan panjang-bobot bersifat allometrik positif, bila b $>3$ (pertambahan bobot lebih cepat daripada pertambahan panjang), dan allometrik negatif, bila $\mathrm{b}<3$ (pertambahan panjang lebih cepat daripada pertambahan bobot).

\section{Pendugaan rata-rata panjang tertangkap}

(Lc)

Pendugaan rata-rata panjang tertangkap dilakukan dengan membuat grafik hubungan antara panjang ikan (sumbu X) dengan jumlah ikan (sumbu Y) sehingga diperoleh kurva berbentuk S. Nilai length at first capture yaitu panjang pada $50 \%$ pertama kali tertangkap dihitung dengan persamaan sebagai berikut (Sparre \& Venema, 1998) :

$$
\begin{aligned}
& \mathrm{S}_{\mathrm{L}} \text { est }=\frac{1}{1+\exp \left(\mathrm{S}_{1}-\mathrm{S}_{2} * \mathrm{~L}\right)} \\
& \mathrm{Ln}\left[\frac{1}{\mathrm{SL}}-1\right]=\mathrm{S}_{1}-\mathrm{S}_{2} * \mathrm{~L} \ldots \ldots \\
& \mathrm{L}_{50 \%}=\frac{\mathrm{S}_{1}}{\mathrm{~S}_{2}} \ldots \ldots \ldots \ldots \ldots \ldots \ldots \ldots \ldots \ldots
\end{aligned}
$$

Di mana :

SL $\quad=$ kurva logistik;

$\mathrm{S}_{1}$ dan $\mathrm{S}_{2}=$ konstanta pada rumus kurva logistik

\section{Pendugaan rata-rata panjang pertama kali matang gonad $(\mathrm{Lm})$}

Pendugaan rata-rata panjang pertama kali matang gonad (length at first maturity) dilakukan sesuai dengan prosedur penghitungan yang dilakukan Udupa 
(1986), melalui rumus :

$$
\mathrm{m}=\mathrm{Xk}+\mathrm{X} / 2-\left(\mathrm{X} \sum \mathrm{pi}\right)
$$

Di mana :

$\mathrm{m}=\log$ ukuran ikan saat pertama matang ovarium

$\mathrm{Xk}=\log$ ukuran ikan dimana $100 \%$ ikan sampel sudah matang

$\mathrm{X}=$ selang $\log$ ukuran (log size increment)

$\mathrm{Pi}=$ proporsi ikan matang pada kelompok ke-i

Rata-rata ukuran ikan pertama matang ovarium diperoleh dari nilai antilog $(\mathrm{m})$.

\section{Estimasi parameter pertumbuhan}

Pendugaan nilai koefisien pertumbuhan $\mathrm{L}_{\text {, }}$ dan $\mathrm{K}$ dilakukan dengan menggunakan metode ELEFAN I, sedangkan $t_{0}$ diperoleh melalui persamaan Pauly (1980). Model pertumbuhan yang digunakan adalah model yang dikemukakan oleh Von Bertalanffy (Sparre \& Venema, 1999) dengan persamaan sebagai berikut:

$\mathrm{L}_{\mathrm{t}}=\mathrm{L}_{\infty}\left(1-\mathrm{e}^{-\mathrm{k}(\mathrm{t}-\mathrm{to})}\right)$

Di mana :

$\mathrm{L}_{\mathrm{t}}=$ ukuran panjang ikan pada saat umur $\mathrm{t}$ tahun $(\mathrm{cm})$

$\mathrm{L}_{w}=$ panjang maksimum ikan yang dapat dicapai

$\mathrm{t}_{0}=$ umur ikan teoritis pada saat panjangnya $0 \mathrm{~cm}$

$\mathrm{K}=$ Koefisien pertumbuhan

\section{Umur}

Nilai dugaan umur teoritis pada saat panjang ikan sama dengan nol $\left(\mathrm{t}_{0}\right)$ ikan kakap merah diperoleh dengan menggunakan rumus (Pauly, 1980) yaitu :

$\log \left(-t_{0}\right) 0.3922-0.2752 \log -1.038 \log \mathrm{K} \ldots(7)$

\section{Mortalitas}

Mortalitas dalam suatu kegiatan perikanan tangkap sangat penting untuk menganalisis dinamika populasi atau stok ikan.

a. Mortalitas alami (M) diduga dengan metode persamaan empiris Pauly (1980) dengan rumus :

$$
\begin{aligned}
\operatorname{Ln} M= & -0,0152-0,279 * \operatorname{Ln~}_{\infty}+0,6543^{*} \operatorname{Ln} \mathrm{K} \\
& +0,4634^{*} \operatorname{Ln} \mathrm{T} \ldots \ldots \ldots \ldots \ldots \ldots \ldots \ldots \ldots \ldots \ldots \ldots \ldots \ldots \ldots \ldots \ldots \ldots \ldots \ldots \ldots \ldots
\end{aligned}
$$

\section{b. Mortalitas Total $(\mathrm{Z})$}

Pendugaan mortalitas total $(Z)$, mengunakan metode Beverton dan Holt dalam (Sparre et al.,1989) yaitu :

$\mathrm{Z}=\mathrm{K} \frac{\mathrm{L}_{\infty}-\overline{\mathrm{L}}}{\mathrm{L}-\mathrm{L}^{\prime}}$

Di mana :

$\overline{\mathrm{L}} \quad$ = Panjang rata - rata kakap merah yang tertangkap $(\mathrm{cm})$

' = Batas terkecil ukuran kelas panjang kakap merah yang telah tertangkap $(\mathrm{cm})$

$\mathrm{K}=$ Koefisien laju pertumbuhan (per tahun)

$\mathrm{L}_{\infty}=$ Panjang asimptotik kakap merah $(\mathrm{cm}) \mathrm{FL}$

c. Mortalitas Penangkapan (F) dengan Laju Eksploitasi (E) ikan kakap merah

Dari hasil pendugaan nilai $Z$ dan $M$, maka mortalitas penangkapan (F) diperoleh dari persamaan;

$\mathrm{Z}=\mathrm{F}+\mathrm{M}$ atau $\mathrm{F}=\mathrm{Z}-\mathrm{M}$

$\mathrm{E}=\mathrm{F} / \mathrm{Z}$

\section{HASIL DAN PEMBAHASAN}

Hasil

\section{Sebaran Panjang Ikan Kakap Merah}

Sebaran panjang total dari 1003 ekor ikan kakap merah (Lutjanus malabaricus) yang diukur menyebar dengan beberapa modus. Panjang ikan terkecil yang tertangkap pada kisaran nilai tengah $13,8 \mathrm{~cm}$ dan terpanjang pada ukuran $81,7 \mathrm{~cm}$. Perkiraan ukuran panjang yang pertama tertangkap (Lc) sekitar 38,2 cmTL dan pertama kali matang gonad (Lm) 45,6 cm .Distribusi frekuensi panjang total ikan kakap merah disajikan pada Gambar 1, distribusi frekuensi panjang kumulatif ikan kakap merah disajikan pada Gambar 2.Ukuran rata-rata panjang pertama kali tertangkap lebih kecil dari ukuran pertama kali matang gonad (LC $38,2 \mathrm{~cm}<\mathrm{Lm} \mathrm{45,6} \mathrm{cm).}$

\section{Hubungan Panjang -Berat}

Hubungan panjang dengan berat tubuh ikan kakap merah diperoleh persamaan $\mathrm{W}=0,075 \mathrm{x}^{2,532}$. Nilai $\mathrm{b}$ dari keseluruhan ikan kakap merah adalah 2,532 dan hasil uji $t$ diperoleh $t_{\text {hitung }}>t_{\text {tabel }}$ yang artinya $b<3$. Ini menunjukkan pola pertumbuhan ikan kakap merah di perairan Belitung bersifat allometrik negatif.

\section{Estimasi Parameter Pertumbuhan}

Berdasarkan pada data panjang (FL) ikan kakap merah (Lutjanus malabaricus) yang diteliti dengan menggunakan rumus model Von Bertalanffy diperoleh nilai parameter pertumbuhan yaitu panjang asimtotik 
$\left(\mathrm{L}_{\infty}\right)=86,1 \mathrm{~cm}$, koefisien pertumbuhan $(\mathrm{K})=0,21$ per tahun, dan umur ikan kakap merah pada saat panjang sama dengan nol $\left(t_{0}\right)=-0,0235$. Dengan demikian persamaan pertumbuhan Von Bertalanffy untuk kakap merah (Lutjanus malabaricus) adalah $\mathrm{L}_{\mathrm{t}}=$ $86,1\left[1-\mathrm{e}^{-0,21(\mathrm{t}+0,0235)}\right]$ yang disajikan dalam Gambar 4 . Panjang asimtotik $\left(\mathrm{L}_{\infty}\right)=86,1 \mathrm{~cm}$ diperkirakan terjadi ketika ikan kakap mencapai umur 36 tahun.

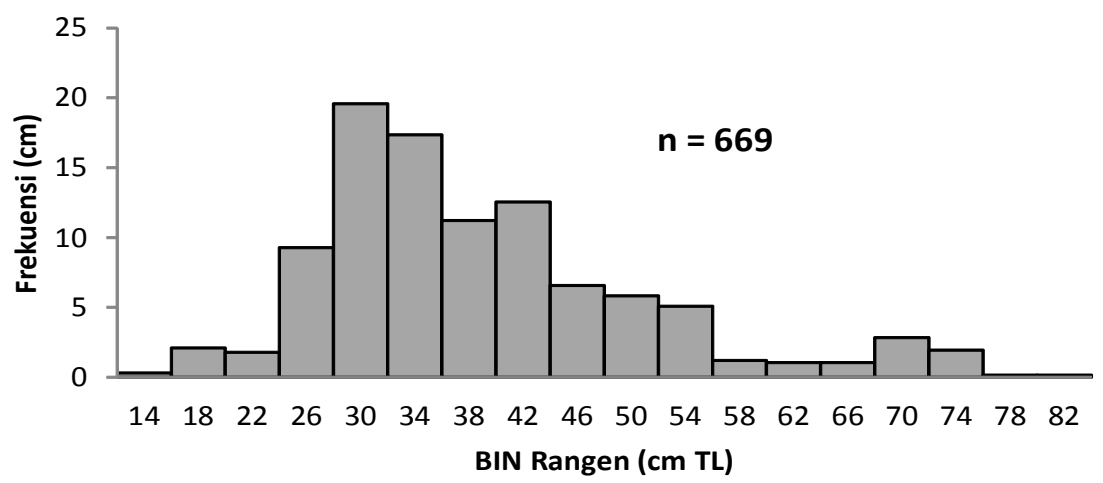

Gambar 1. Distribusi frekuensi panjang total ikan kakap merah (Lutjanus malabaricus).

Figure 1. The frequency distribution of total length red snapper (Lutjanus malabaricus).

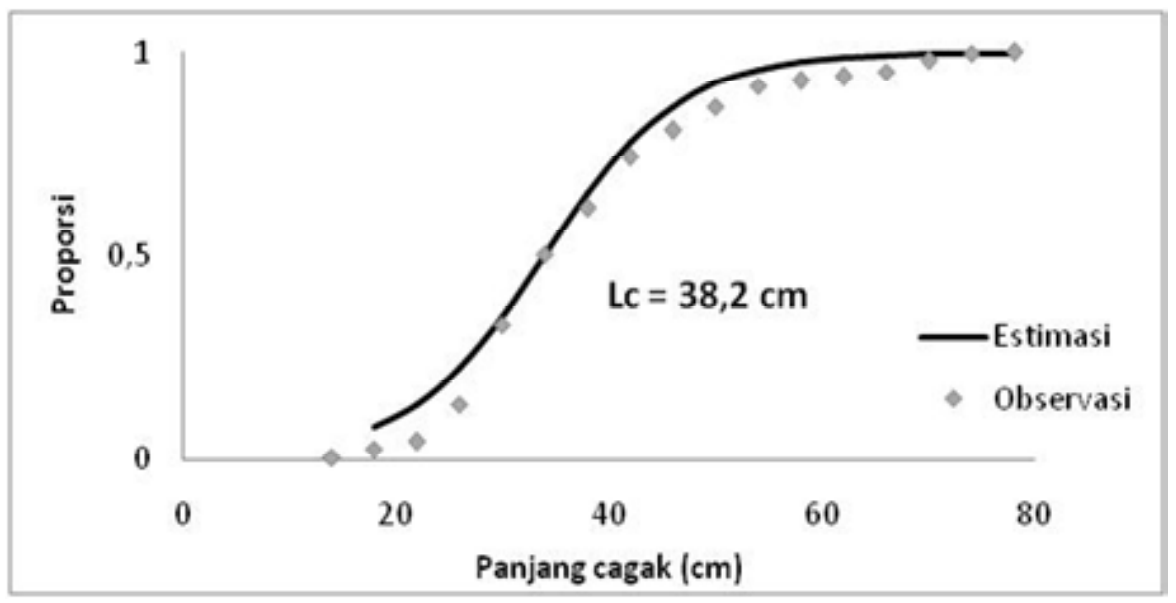

Gambar 2. Distribusi frekuensi panjang kumulatif ikan kakap merah (Lutjanus malabaricus).

Figure 2. The frequency distribution of cumulative length red snapper (Lutjanus malabaricus).

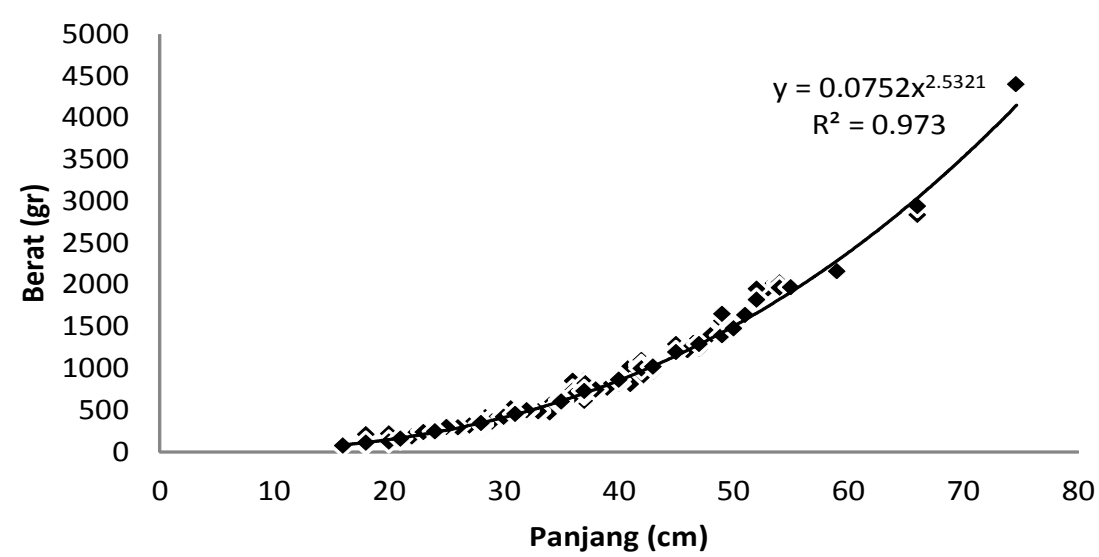

Gambar 3. Hubungan panjang-berat ikan kakap merah (Lutjanus malabaricus).

Figure 3. Fish length-weight relationship red snapper (Lutjanus malabaricus). 


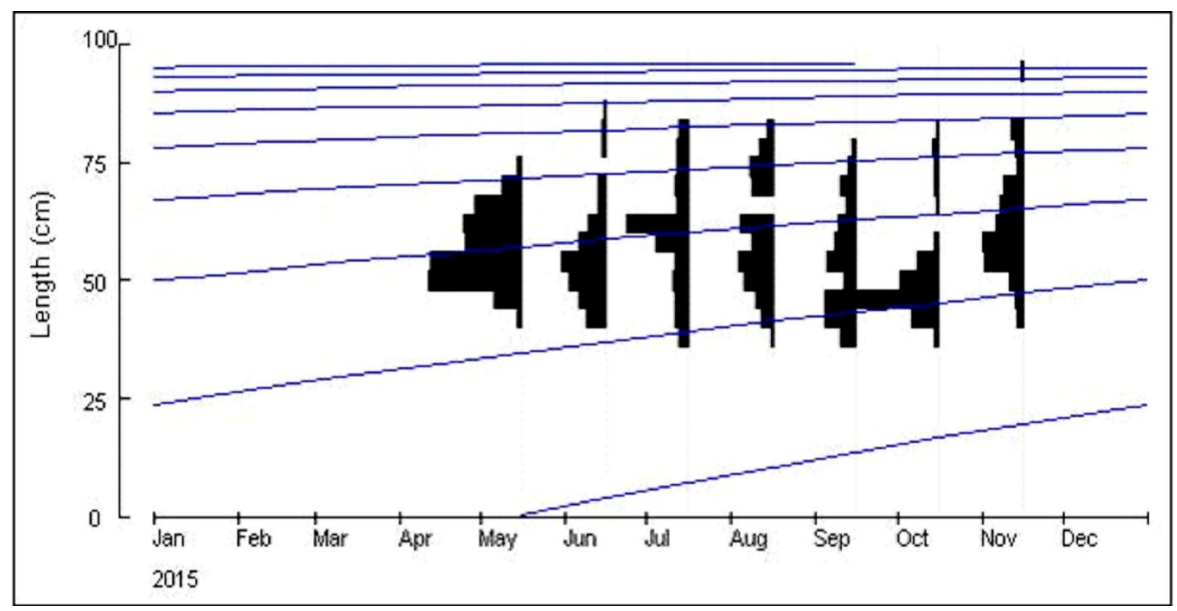

Gambar 4 . Kurva pertumbuhan ikan kakap merah (Lutjanus malabaricus).

Figure 4. The growth curve of red snapper (Lutjanus malabaricus).

\section{Umur}

Berdasarkan pada data panjang (FL) ikan kakap merah (Lutjanus malabaricus) yang diteliti dengan menggunakan rumus model Von Bertalanffy diperoleh nilai parameter pertumbuhan yaitu panjang asimtotik $\left(\mathrm{L}_{\propto}\right)=86,1 \mathrm{~cm}$, koefisien pertumbuhan $(\mathrm{K})=0,21$ per tahun, dan umur ikan kakap merah pada saat panjang sama dengan nol $\left(t_{0}\right)=-0,0235$. Dengan demikian persamaan pertumbuhan Von Bertalanffy untuk kakap merah (Lutjanus malabaricus) adalah $\mathrm{L}_{\mathrm{t}}=$ $86,1\left[1-\mathrm{e}^{-0,21(\mathrm{t}+0,0235)}\right]$ Gambar 5.

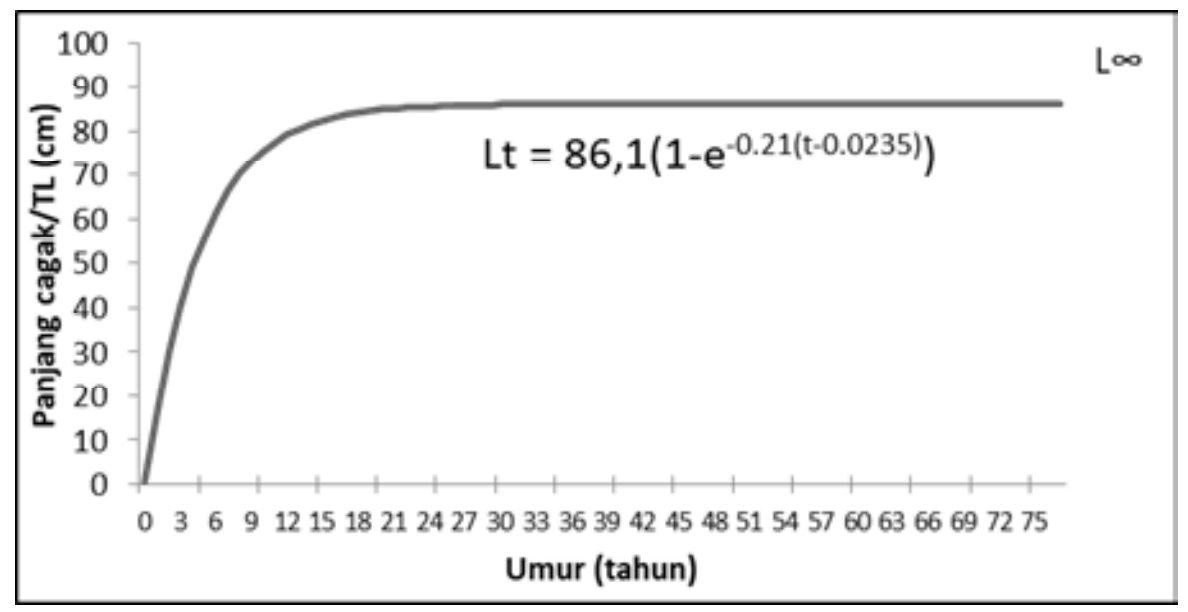

Gambar 5. Kurva pertumbuhan Von Bertalanffy ikan kakap merah.

Figure 5. The growth rate curve von Bertalanffy of red snapper.

\section{Mortalitas}

Nilai mortalitas alami $(=\mathrm{M})$ adalah 0,49 per tahun dan nilai mortalitas karena penangkapan $(=\mathrm{F})$ adalah 0,59 per tahun, sehingga mortalitas total $(=\mathrm{Z}) 1,08$ per tahun. Untuk nilai eksploitasi/tingkat pemanfaatan (=E) ikan kakap merah (Lutjanus malabaricus) di Belitung adalah 0,55. Hal itu menunjukkan bahwa tingkat pemanfaatannya mengalami lebih tangkap.

\section{Pembahasan}

Ukuran rata-rata panjang pertama kali tertangkap lebih kecil dari ukuran pertama kali matang gonad (LC

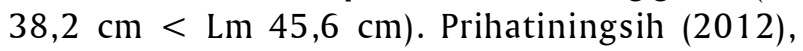
menyatakan bahwa nilai Lc kakap merah (Lutjanus malabaricus) di perairan Kotabaru (Kalimantan Selatan) yaitu 40,5 cmFL. Pada penelitian Wahyuningsih (2013), juga diperoleh $\mathrm{Lc}<\mathrm{Lm}(38,51 \mathrm{cmFl}<50 \mathrm{cmFl})$. Nilai Lc yang lebih kecil dari Lm dapat diartikan bahwa sebagian besar ikan-ikan yang tertangkap belum 
sempat melakukan pemijahan, kondisi ini tidak baik secara biologi. Berdasarkan garis kurva pertumbuhan, diketahui bahwa musim pemijahan kakap merah (Lutjanus malabaricus) di LCS terjadi pada bulan Mei-
Juni. Musim ini berbeda dengan di Indonesia Timur, yaitu di Laut Arafura yang memiliki pola pemijahan dengan dua puncak: Januari-Maret dan Oktober (Fry et al., 2009).

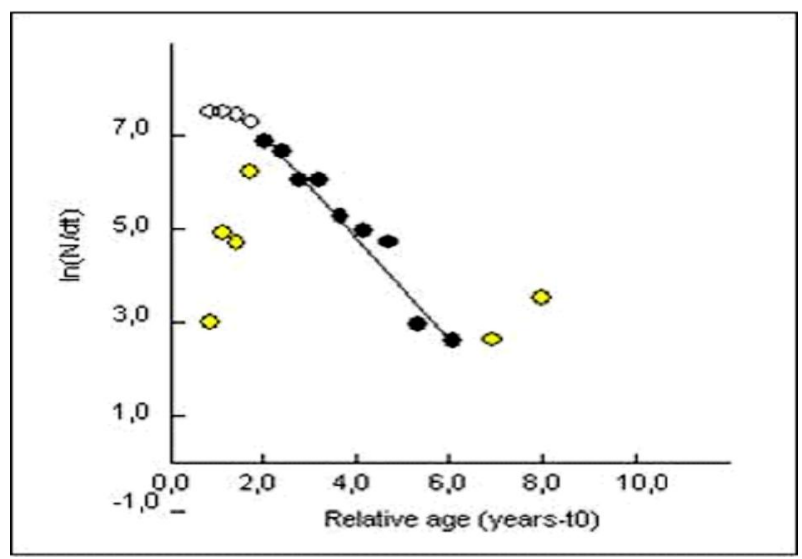

Gambar 6. Kurva konversi panjang terhadap penangkapan ikan kakap merah.

Figure 6. Length - converted catch curve of red snapper.

Pertambahan panjang lebih cepat dibandingkan pertambahan beratnya. Hasil ini sama dengan penelitian ikan kakap merah di perairan Sape dan Kupang dengan pola pertumbuhannya bersifat allometrik negatif (Andamari et al., 2004). Hasil yang berbeda terjadi pada penelitian (Prihatiningsih, 2012; Wahyuningsih, 2013), yang menyatakan bahwa hubungan panjang bobot ikan kakap merah (Lutjanus malabaricus) di perairan Kalimantan Selatan dan Brondong (Jawa Timur) pola pertumbuhannya bersifat issometrik. Menurut Effendie (2002), pertumbuhan suatu ikan dipengaruhi oleh keturunan, jenis kelamin, umur, parasit, penyakit, ketersediaan makanan dan suhu perairan. Secara umum, nilai b tergantung pada kondisi fisiologis dan lingkungan seperti suhu, $\mathrm{pH}$, salinitas, letak geografis (Jenning et al., 2001) dan juga kondisi biologis seperti perbedaan koefisien perkembangan gonad ini disebabkan faktor biologis seperti perkembangan gonad dan ketersediaan makanan (Froese, 2006). Menurut Prihatiningsih et al., (2017), bahwa ikan kakap merah tergolong ikan karnivora di mana makanan utamanya adalah ikan dan kepiting (Portunidae) .

Berdasarkan pada data panjang (FL) ikan kakap merah (Lutjanus malabaricus) yang diteliti dengan menggunakan rumus model Von Bertalanffy diperoleh nilai parameter pertumbuhan yaitu panjang asimtotik (L”) $=86,1 \mathrm{~cm}$, koefisien pertumbuhan $(\mathrm{K})=0,21$ per tahun, dan umur ikan kakap merah pada saat panjang sama dengan nol $\left(\mathrm{t}_{0}\right)=-0,0235$. Dengan demikian persamaan pertumbuhan Von Bertalanffy untuk kakap merah (Lutjanus malabaricus) adalah $\mathrm{L}_{\mathrm{t}}=$ $86,1\left[1-\mathrm{e}^{-0,21(\mathrm{t}+0,0235)}\right]$. Panjang asimtotik $\left(\mathrm{L}_{\curvearrowright}\right)=86,1 \mathrm{~cm}$ diperkirakan ketika ikan kakap mencapai umur 36 tahun. Menurut Gulland (1983), apabila nilai K yang kurang dari 0,5 menunjukkan bahwa ikan ini mempunyai pertumbuhan yang lambat. Ikan dengan pertumbuhan lambat memiliki umur yang panjang. Menurut Newman et al. (2000) ikan kakap merah jenis Lutjanus malabaricus mempunyai umur yang cukup panjang dapat mencapai 20 tahun.

Untuk nilai eksploitasi/tingkat pemanfaatan (=E) ikan kakap merah (Lutjanus malabaricus) di Belitung adalah 0,55. Hal itu menunjukkan bahwa tingkat pemanfaatannya sudah over exploited. Menurut Gulland (1983), tingkat pemanfaatan optimum berada pada saat $E=0,5$. Tingkat pemanfaatan ikan demersal di WPP 711 Laut Cina Selatan telah melewati jumlah tangkapan yang diperbolehkan dengan nilai E mencapai 1,09 dari potensi ikan demersal 482.200 ton/tahun (Suman et al., 2014). Kondisi tersebut perlu kehatihatian dalam melakukan pengelolaan. Adanya pelarangan alat tangkap trawl dan sejenisnya (Moratorium) diharapkan dapat mengembalikan kelestarian sumber daya ikan.

\section{KESIMPULAN}

Parameter populasi ikan kakap merah (Lutjanus malabaricus) di Laut Cina Selatan memiliki koefisien pertumbuhan $(=K)$ sebesar 0,21 per tahun dan panjang asimtotik (=L”) 86,10 cm. Laju mortalitas alami (=M) 0,49 pertahun dan mortalitas penangkapan $(\mathrm{F})$ sebesar 0,59 per tahun, sehingga diperoleh nilai kematian total $(=\mathrm{Z})$ 1,08 pertahun. Panjang pertama kali tertangkap (= Lc) sebesar 38,2 cmTL dan panjang pertama kali matang gonad (=Lm) 45,6 cmTL dengan musim 
pemijahan diperkirakan bulan Mei-Juni. Status tingkat pemanfaatan ikan kakap merah $(=\mathrm{E})$ sebesar 0,55. Tingkat pemanfaatan ikan kakap sudah over exploited sebesar 9 persen.

\section{PESANTUNAN}

Tulisan ini merupakan kontribusi dari kegiatan hasil penelitian pengkajian sumberdaya ikan di WPP 711- Laut Cina Selatan, Tahun 2015 di Balai Penelitian Perikanan Laut, Jakarta.

\section{DAFTAR PUSTAKA}

Andamari, R., Milton, D., Velde, T. V., \& Sumiono, B. (2004). Pengamatan aspek biologi reproduksi ikan kakap merah (Lutjanus malabaricus) dari perairan Sape dan Kupang. Jurnal Penangkapan Perikanan Indonesia Sumber Daya dan Penangkapan, 10(4), 65-75.

Edwards, R. R. C., \& Shaher, S. (1991). The biometrics of marine fishes from the Gulf of Aden. Fishbyte Journal, 9(2) 27-29.

Effendie, I. M. (2002). Biologi Perikanan. Yayasan Pustaka Nusantara. Yogyakarta. 163 pp.

Ffoese, R. (2006). Cube law, condition factor and weight-length relationships: history, metaanalysis and recommendations. Journal of Applied Ichthyology, 22(5), 241-253.

Fry G. C., Milton D.A., Velde. V.T., Stobutzki. I., Andamari, R., Badrudin., \& Sumiono, B., (2009). Reproductive dynamics and nursery habitat preferences of two commercially important red snappers Lutjanus erythropterus and Lutjanus malabaricus. Fisheries Science Journal. 75:145158

Fry G.C., \& Milton, D.A. (2009). Age, growth and mortality estimates for populations of red snappers Lutjanus erythropterus and Lutjanus malabaricus from northern Australia and eastern Indonesia. Fisheries Science. Japan. 75(7), 1219 1229.

George, M. (2012). Fisheries protections in the context of the geo-political tensions in the South China Sea. Journal of Maritime Law \& Commerce 43 (1): 85-128.

Gulland, J. A. 1983. Fish stock assessment. A Manual of Basic Methods. John Wiley \& Sons. Chicester. $233 \mathrm{p}$.

Herianti, I., \& Djamal, R. (1993). Dinamika populasi kakap merah Lutjanus malabaricus (Bloch and Schneider) di perairan Utara Laut Jawa. Jurnal Penelitian Perikanan Indonesia, 78, 18 - 25.

McManus, J.W., Shao, K.T., \& Lin, S.Y. (2010). Toward establishing a Spratly Island International Marine
Peace Park: ecological importance and supportive collaborative activities with an emphasis on the role of Taiwan. Ocean Development $\&$ International Law 41: 270-280.

Newman.S.J. (2002). Growth rate, age determination, natural mortality and production potential of the scarlet seaperch,Lutjanus malabaricus Schneider 1801 , off the Pilbara coast of north-western Australia. Fisheries Research, 58(2) 215-225.

Newman, S. J., Cappo, M \& Williams, D. (2000). Age, growth, mortality rates, and corresponding yield estimates using otoliths of the tropical red snappers, Lutjanus erythropterus, L.malabaricus, and L. Sebae, from the central Great Barrier Reef. Fisheries Research 48, 1-14.

Pauly, D. 1980. A selection of simple methods for the assessment of tropical fish stocks. FAO Fish. Circ. FIRM/C 729. Roma. 54 pp.

Perangin-angin, R, Sulistiono, Kurnia R, Fahrudin A, Suman A. 2016. Kepadatan dan stratifikasi komposisi sumber daya ikan demersal di Laut Cina Selatan (wpp - nri 711). Jurnal Penelitian Perikanan Indonesia. 22(3), 161-172.

Prihatiningsih. (2012). Pertumbuhan, umur dan mortalitas ikan kakap merah (Lutjanus malabaricus) dari perairan Kotabaru (Pulau Laut) Kalimantan Selatan. Prosiding. Seminar Nasional Perikanan Tangkap. Manado 30-31 Oktober 2012. Hal 373383.

Prihatiningsih., Kamal, M.M., Rahmat Kurnia., \& Suman, A. (2017). Hubungan Panjang-Berat, Kebiasaan Makanan, Dan Reproduksi Ikan Kakapmerah (Lutjanus Gibbus: Famili Lutjanidae) Di Perairan Selatan Banten. Bawal, 9(1), 21-32.

Sparre, P. \& S. C. Venema. 1998. Introduksi pengkajian stok ikan tropis. Badan Penelitian dan Pengembangan Perikanan (Terjemahan) : Introduction to Tropical fish stock assessment. FAO Fish Tech. Paper. 306.(1) 376 pp.

Sriati. (2011). Kajian Bio-Ekonomi Sumberdaya Ikan Kakap Merah yang didaratkan di Pantai Selatan Tasikmalaya, Jawa Barat. Jurnal Akuatika. 2(2 ), 7990.

Suman, A., Wudianto., Sumiono, B., Irianto, H.E., Badrudin., \& Amri, K. (2014). Potensi Lestari dan Tingkat Pemanfaatan Sumberdaya Ikan di WPP RI. Balai Penelitian Perikanan Laut: $199 \mathrm{Hlm}$.

Udupa, K. S. (1986). StatisticaL method of estimating the size of first maturity in fish. Fishbyte ICLARM. Manila. 4(2), 8-1.

Wahyuningsih., Prihatiningsih., \& Ernawati, T. (2013). Parameter Populasi Ikan Kakap Merah (Lutjanus Malabaricus)Di Perairan Laut Jawa Bagian Timur. Bawal. Vol. 5 (3) Hal: 175-179. 